\title{
A BRAZILIAN HEPATITIS A VIRUS ISOLATED AND ADAPTED IN PRIMATE AND PRIMATE CELL LINE AS A CHANCE FOR THE DEVELOPMENT OF A VACCINE
}

\author{
A. M. GASPAR; C. L. VITRAL; R. S. MARCHEVSKY*; C. F. T. YOSHIDA \& H. G. SCHATZMAYR
}

Departamento de Virologia, Instituto Oswaldo Cruz, *Bio-Manguinhos - FIOCRUZ, Av. Brasil 4365 , 21045-900 Rio de Janeiro, RJ, Brasil

Hepatitis $A$ is caused by a member of the genus Hepatovirus within the family Picornaviridae (R. I. B. Francki, C. M. Fauquet, D. L. Knudson, F. Brown (eds) 1991, Arch of Virol., Suppl., 2: 320-6). The virus has a great importance for Brazilian Public Health because it is widespread in the environment. On one hand infection in children developes often as a subclinical or mild disease. On the other hand, overt hepatitis developes in the majority of adults, and the incidence of subclinical infection is very low (F. Sutmoller et al., 1982, Mem. Inst. Oswaldo Cruz, 77: 9-17). Hepatitis A virus (HAV) is responsible for $50 \%$ of acute hepatitis diagnosed in the National Reference Center for Viral Hepatitis, Virology Department, FIOCRUZ. Epidemiological data show that approximately $90 \%$ of the adult Brazilian population has antibodies anti-HAV IgG (A. R. N. Abuzwaida et al., 1987, Rev. Inst. Med. Trop. São Paulo, 29: 219-23) in opposition to developed countries, in which the prevalence of susceptible adults is very high with risk of huge outbreaks.

Some HAV strains have been isolated in several parts of the world and adapted to human and primate cell cultures (P. J. Provost \& M. R. Hilleman, 1979, Proc. Soc. Exp. Biol. Med., 160: 213-21; B. Flehmig, 1980, Med. Microbiol. Immunol, 168: 239-248; D. W. Bradley et al., 1984, J. Med. Virol., 14: 37386). Many researchers are also working on the development of attenuated and inactivated vaccines (J. M. Johnston et al., 1988, J. Infect. Dis., 157: 1203-11; B. Flehmig et al., 1989, Lancet, 13: 1039-42).

Hepatitis A virus has a slow growth on cell cultures often with low antigen titer and do

Received 6 March 1992.

Accepted 3 July 1992. not develop cytopathic effect (B. Flchmig, 1981, Med. Microbiol. Immunol., 170: 73-81; D. A. Anderson et al., 1985, Intervirology, 21: 26-32; C. M. Wheeler et al., 1986, J. Clin. Microbiol., 23: 434-40).

A Brazilian hepatitis A virus (HAF-203) was isolated in fetal rhesus hidney cells-FRhK4 from faeces collected from an infected child in the beginning of the acute phase, (Gaspar et al., 1992, Braz. J. Med. Biol. Res., in press). A great tool for this study was the availability of tests, standardized by our group, for the detection of viral antigen (HAVAg) and RNA. Enzyme immunoassay (EIA-HAVAg) was applied for viral protein detection; specific human anti-HAV IgG, from serum of individuals recovering from hepatitis $\mathrm{A}$ infection, was purified by a combination of ammonium sulfate precipitation followed by anion exchange chromotography and used to coat the surface of the solid phase and conjugated with horseradish peroxidase. RNA was detected by cDNA-RNA hybridization using a ${ }^{32} \mathrm{p}$ labelled nick translated cDNA probe kindly supplied by J. R. Ticehurst (NIH, Bethesda, USA).

After the adaptation of HAF-203 in cell culture, we selected fast-growing virus particles with a higher antigenic titer. Through the follow-up of the viral growth curve in the third passage, after the adaptation phase to the cellular system, we could observe maximum levels of RNA on the 21 st day and of viral protein on the 49th day. Based on these data, sequential passages were performed always using as inoculum the cellular lysate from the 21 st day. Now, we have reduced the time for maximum protein release from 49 days p. i. (lst passage) to 7 days p. i. (8th passage).

The infectivity of HAF-203 was demonstrated in South-American marmosets Callithrix jacchus (C. L. Vitral, 1991, Infecção intragás- 
trica em Callithrix jacchus com uma cepa brasileira do virus da hepatite $A-H A F-203$, Thesis, Instituto Oswaldo Cnuz, 131p.). In the acute phase, accentuated hepatic lesions were observed together with the elevation of aminotransferases. HAVAg was also demonstrated in hepatic and renal tissues using the technique of immunoperoxidase. We could observe that the course of experimental infection in these animals showed significant correlation to natural infection in man, as described by
Teixeira et al., 1982 (Liver, 2: 53-60). These data were previously demonstrated with other species of marmosets (P. Karayiannis et al., 1986, J. Med. Virol., 18: 261-76) and chimpanzees (A. N. Schulman et al., 1976, J. Infect. Dis., 134: 80-4). C. jacchus, which was shown to be susceptible to hepatitis A virus, can now be used as an animal model for hepatitis A vaccine control. Currently, studies are being developed with the aim of cloning and sequencing the genome of HAF-203. 